\title{
FANTASTYKA POLITYCZNA CZY KONIECZNOŚĆ? \\ PORTUGALSKA AFRYKA, NIKARAGUA, BOLIWIA I EKWADOR \\ W POLSKICH PLANACH KOLONIALNYCH
}

\author{
U ŹRÓDEt KOLONIALNYCH ASPIRACJI
}

K

olonialne aspiracje międzywojennej Polski, dla wielu obserwatorów kuriozalne, budzą w ostatnich latach coraz większe zainteresowanie. W tym artykule skupię się na kilku mniej znanych kartach polskiej akcji kolonialno-osadniczej w portugalskiej Afryce (Angola i Mozambik) oraz Ameryce Łacińskiej, w takich krajach jak Nikaragua, Dominikana, Ekwador, Paragwaj i Boliwia. Choć o wiele większy strumień emigrantów kierował się do Argentyny i Brazylii (co znalazło odbicie w opracowaniach i badaniach), warto przyjrzeć się tym mniej znanym planom i faktom.

Władze Drugiej Rzeczypospolitej borykały się z bolesnymi problemami społecznymi i gospodarczymi, jak bezrobocie, zacofanie, przeludnienie wsi i w efekcie bieda, oraz konfliktami etnicznymi, zwłaszcza na kresach wschodnich. Emigracja i kolonizacja miały pomóc w rozwiązaniu tych kwestii, zmniejszając napięcia społeczne oraz odsetek mniejszości etnicznych, głównie Ukraińców i Żydów. Niezależnie od zarysowanych powyżej przesłanek, istniały też względy prestiżowe. W latach międzywojennych, jak podkreślał Andrzej Skrzypek, „powszechnie akceptowana była teza, iż o możliwościach rozwoju gospodarczego danego państwa decyduje wielkość posiadanych przez nie kolonii”" Ów badacz pisał, iż co prawda

Dr Michat JARNECKI jest pracownikiem Wydziału Pedagogiczno-Artystycznego Uniwersytetu im. A. Mickiewicza w Kaliszu. mmjarnecki@poczta.onet.pl ..... .

A. Skrzypek, W kręgu Międzymorza i taktyki balansowania (maj 1935 - wrzesień 1938),

w: Historia dyplomacji polskiej, T. IV pod red. P. Łossowskiego, Warszawa 1995, s. 520. 
Rzeczypospolita wprost kolonii się nie domagała, ale zabiegała o możliwość zwiększenia emigracji i dostępu do surowców².

Sprawa była bardziej złożona. W kraju podobne sugestie i postulaty zostały jednak sformułowane. Już podczas konferencji pokojowej w Paryżu taki wniosek złożyli Kazimierz Warchałowski z brazylijskiej Polonii, prof. Jan Dybowski, agronom, jeszcze wówczas obywatel Francji, Leon Bułowski, a nawet ludowy działacz Tomasz Dąbal³ ${ }^{3}$ który dokonał notabene ciekawej ewolucji od PSL „Piast” do KPP. Były też tego dowodem interpelacje i apele Senatu formułowane od końca lat dwudziestych skierowane pod adresem rządu, co miało stanowić presję na władze, a w przypadku ostatniej z 1933 r., częściowo wymusiło pewne reakcje ${ }^{4}$. Istotną rolę mogły też odegrać działania Związku Pionierów Kolonialnych, powołanego zresztą nie bez udziału urzędników państwowych, z Kazimierzem Głuchowskim na czele. Ci wcześniej działali w Polskim Towarzystwie KoIonialnym (od 1924 r. Polskim Towarzystwie Emigracyjnym)5. Nie mogło też zabraknąć głosu Ligi Morskiej i Kolonialnej (LMiK), powołanej jesienią 1930 r., jak i jej poprzedniczki w latach 1924-1930 występującej pod nazwą Ligi Morskiej i Rzecznej (LMiR). Ta masowa prorządowa organizacja propagowała przede wszystkim przekształcenie Rzeczypospolitej w państwo morskie oraz ekspansję gospodarczą i kolonialną. Wśród argumentów pojawił się też i taki, iż Polska jako członek zwycięskiej Ententy powinna zostać uhonorowana odpowiednim odsetkiem obszaru poniemieckich kolonii.

$\mathrm{Na}$ przełomie lat dwudziestych i trzydziestych rozgorzały dyskusje o ewentualnym nowym rozdaniu i modyfikacji mandatów Ligi Narodów, o co wnosiły same Niemcy pozbawione na mocy traktatu wersalskiego kolonii. Wspomniany wyżej K. Głuchowski argumentował, iż Rzeczypospolitej należy się około 10\% byłych niemieckich kolonii, z racji pominięcia Polski przy podziale floty Rzeszy i udziału w strukturze demograficznej upadłego cesarstwa. Przemawiać za tym miały racje demograficzne (spory przyrost naturalny) i gospodarcze, nie mówiąc o prestiżowych. Polska miałaby albo sama uzyskać mandat Ligi (najczęściej wymieniane były Kamerun lub Togo), albo sprawować administrację na zasadzie kondominium z którymś z mocarstw kolonialnych ${ }^{6}$. Postulat pozyskania kolonii pojawiał się też w toku kolejnych prac, dyskusji i zjazdów tej organizacji. Istniało na początku lat trzydziestych przekonanie o rychłej rewizji systemu mandatowego Ligi Narodów (nieuzasadnione, jak się potem okazało) ${ }^{7}$.

2 Ibidem.

T. Białas, Liga Morska i Kolonialna 1930-1939, Gdańsk 1983, s. 167.

Archiwum Akt Nowych (d. AAN), zespół MSZ, sygn. 9579, mikrofilm (mkf.) B.25989, k. 4 pismo Marszałka Senatu do premiera z 30.03.1929, k. 10 pismo MSZ do premiera z 1929 (bez daty dziennej), gdzie jest mowa o trzeciej już rezolucji Senatu RP; k. 12, 31.03.1930, pismo Marszałka Senatu Hipolita Gliwica do Rady Ministrów, aby przy nowym podziale mandatów Ligi Narodów uzyskać coś dla Polski; ostatnia rezolucja Senatu wzywająca władze RP do zabiegów o uzyskanie terytorium mandatowego Ligi Narodów (LN) została uchwalona 28.02.1933 r., co zmusiło MSZ do zbierania z pomocą placówek w Wielkiej Brytanii i Francji informacji i materiałów o byłych koloniach Niemiec, w: AAN, Ambasada RP w Paryżu, teczka 72, k. 154-156, Apoloniusz Zarychta - naczelnik Wydziału Polityki Emigracyjnej MSZ do ambasad w Londynie i Paryżu oraz konsulatu w Marsylii, 24.04.1933.

5 Związek Pionierów Kolonialnych, założona w lutym 1928 r. organizacja mająca na celu uzyskanie obszarów ekspansji dla Polaków. Jej założycielami byli Kazimierz Głuchowski, były konsul RP w Kurytybie (prezes), prof. Ludwik Kulczycki (zastępca prezesa) i Michał Pankiewicz. Za główny cel członkowie ZPK stawiali sobie pozyskanie kolonii dla Polski lub terenów osadniczych dla narodu polskiego. ZPK został wchłonięty przez Ligę Morską i Kolonialną (LMiK), działał jako odrębna sekcja tej organizacji: źródło: http://pl.wikipedia.org/wiki/Związek Pionierów Kolonialnych oraz T. Białas, Liga Morska i Kolonialna 1930-1939, s. 167.

6 K. Głuchowski, Akcja kolonialna LMiR, „Morze”, 1928, nr 12, s. 27-29; AAN, MSZ, sygn. 9583, Mkf. 25993, k. 2-12, Memoriał prof. S. Pawłowskiego do MSZ w sprawie przyznania Togo lub Kamerunu z 1936 r.; T. Białas, Liga Morska..., s. 177. Kamerun występował z tej racji, iż jednym z jego odkrywców był sławny podróżnik S. Szolc-Rogoziński.

7 Na drugim Walnym Zjeździe Delegatów LMiR podjęta została uchwała o prawie Polski do posiadania koIonii i powierzeniu Zarządowi Głównemu zdania przekonania rządu polskiego do tej idei, w: // Walny 
Konkretyzację projektów kolonialnych przyniósł III Walny Zjazd LMiR (na nim doszło do zmiany nazwy na LMiK). Polityka kolonialna miała się stać jednym z fundamentalnych warunków ekonomicznej niezależności. W następnych latach publicyści związani z LMiK powracali do tych wątków. Swój udział w podgrzewaniu tej swoistej kolonialnej gorączki miały najpopularniejsze dzienniki, jak „IKC” oraz pisarze, publicyści i zarazem podróżnicy, współpracujący z MSZ lub nawet zatrudnieni przez resort, jak Jerzy Makarczyk, Arkady Fiedler, Jerzy Giżycki i Maria Zakrzewska, wnoszący w atmosferę publicznego dyskursu klimat wielkiej przygody.

Również sam rząd w roku 1936, jeśli nawet nie wcześniej, zastanawiał się poważnie nad wysunięciem odpowiednich postulatów. Był to czas ujawnienia niczym już nie skrywanych aspiracji rewizjonistycznych III Rzeszy - nie wyłączając ich pretensji do byłych posiadłości zamorskich oraz Japonii i Włoch. W polskim MSZ zaczęły się prace studyjne i odbyły specjalne konferencje poświęcone tematowi „polskich żądań kolonialnych”. Miało to pomóc w rozwiązaniu problemu przeludnienia i kwestii żydowskiej oraz uzyskaniu bazy surowcowej. Dowodem zainteresowania stało się powołanie Międzynarodowego Towarzystwa Osadniczego (MTO) w kwietniu 1936 r., dysponującego kapitałem początkowym w wysokości pół miliona złotych. Obszarem rokującym największe nadzieje miał być trójkąt na pograniczu Brazylii, Argentyny i Paragwaju, gdzie według przyjętych założeń miało zostać sprowadzonych około 50 tys. osadników i to niezależnie od istniejącej już Polonii w dwóch pierwszych państwach ${ }^{9}$.

Podobna argumentacja, a nawet wzmocniona, jak w przypadku działaczy LMiK, powróci w połowie lat trzydziestych w poufnej korespondencji MSZ z Delegacją RP przy Lidze Narodów. Polska „jako szóste mocarstwo Europy pod względem zaludnienia i obszaru zasługuje, aby posiadać własne bazy surowcowe i teren ekspansji demograficznej"10. Interpretowane w taki sposób postulaty implikowały w sumie osobliwe zrozumienie dla Włoch po ataku na Abisynię i głosy za zniesieniem nałożonych na nie sankcji. W poufnej dokumentacji MSZ spotkać możemy tezy, iż Polska widzi w tym konflikcie dowód, że prężne populacyjnie państwo znalazło się w nieznośnej sytuacji demograficznej, nie mając terytoriów mandatowych ${ }^{11}$.

....

Zjazd Delegatów LMiR, „Morze”, 1929, nr 9-10, s. 18; z kolei uspokajał emocje członek Delegacji RP przy Lidze Narodów, T. Gwiazdowski, tłumaczac, iż mandaty - tzn. obszary mandatowe, „poza tureckimi sa bezterminowe i pogłoski o nowym rozdaniu sa nieuzasadnione, posiadajac charakter plotek", w: AAN, MSZ, sygn. 9579, Mkf. 25989, k. 16-17 odpowiedź z Delegacji PR przy LN, 8.04.1930; T. Białas, Liga Morska..., s. 170-171.

8 Wśród wniosków znalazły się postulaty: „nasilenia polskiego przemysłu i handlu na tereny polskiej ekspansji", wsparcia polskiej ekspansji na wybrane obszary, gdzie Polacy stanowiliby zwartą i liczną grupę - pozwoliłoby to zachować narodową tożsamość, powołania na wyższych szkołach wydziałów kolonialnych, a nawet utworzenia specjalnej placówki wyższej oraz powołania Banku Kolonialnego wspierającego tego typu aktywność, w: III Walny Zjazd Delegatów LMiR, „Morze”, 1930, nr 11, s. 23-24; na emigracji, już z pewnej perspektywy, pisał o tym W. Drymmer, Zagadnienie żydowskie w Polsce w latach 1935-1939, „Zeszyty Historyczne”, t. 13, Paryż 1968, s. 55-57 oraz T. Białas, s. 171-172, 175-178.

9 AAN, MSZ, sygn. 9586, Mkf. 25996 k. 1-6. Protokół z konferencji w sprawach kolonialnych, 9.05.1936, k. 8-12, Protokół z konferencji w sprawach kolonialnych, 22.06.1936; też sygn. 9585, Mkf. 25995, w teczce plany koncentracji polskiej akcji osadniczej na pograniczu Argentyny, Paragwaju i Brazylii z lat 1936-1937, z przybliżonymi kosztami, które do 1947 r. (!) sięgać miały ponad 37 mln złotych; AAN, Protokoły Rady Ministrów (PRM), Akta 72-1, s. 168 z notatką o powołaniu MTO; wcześniejszego zainteresowania rząu dowodziłyby tzw. Tezy kolonialne i ich ekonomiczne uzasadnienie z lat 1935-1936, w: AAN, MSZ, sygn. 9581 i 9582, Mkf. 25991 i 25992; wreszcie, podobne myśli pojawiły się już w latach 1933-1934 na marginesie Sprawozdania i wytycznych z całokształtu spraw emigracyjnych, sygn. 9580, Mkf. 25990, k. 66-119; oraz T. Białas, s. 180-183.

10 AAN, MSZ, sygn. 9583, Mkf. 25993, k. 56-57, Instrukcja z MSZ do B. Celińskiego, członka polskiej Delegacji z czerwca 1936 r. - do pisma dołączona została mapka Kamerunu..

11 AAN, MSZ, sygn. 9582, Mkf. B. 25992, k. 38, notatka z przełomu 1935/1936 r. 
Rząd jednak unikał stawiania na forum międzynarodowym polskich oczekiwań kolonialnych w sposób kategoryczny i jednoznacznie oficjalny. Kierownictwo resortu zdawało sobie sprawę z tego, iż nie tyle może to Polskę ośmieszyć, ile zaniepokoić mocarstwa, a przede wszystkim uzasadniać niemieckie żądania rewindykacji kolonialnych. Oficjalnie polskie aspiracje ograniczały się do dostępu do surowców i obszarów osadniczych, w tym dla pochodzących z RP Żydów i Ukraińców, na forum Ligi Narodów ${ }^{12}$. Bardziej skonkretyzowane oczekiwania organizacji społecznych, nawet bliskich rządowi, swoistych harcowników na pierwszej linii kontrowersyjnych problemów, miały na celu wywarcie presji i stworzenie odpowiedniej atmosfery, aby móc w odpowiedniej chwili wystąpić z postulatami kolonialnymi. Nieoficjalny charakter tych wystąpień czy enuncjacji pozwalał też wycofać się w odpowiedniej chwili, aby nie stracić twarzy, co też słusznie zauważył Marek Arpad Kowalski w swej książce o charakterze popularnym ${ }^{13}$.

Pewne nadzieje rozbudziła w Warszawie wizyta francuskiego ministra spraw zagranicznych Yvona Delbosa w grudniu 1937 r., życzliwie odnoszącego się do polskich aspiracji kolonialnych, szczególnie w kwestii dopuszczenia do eksploatacji surowców i możliwości osiedleńczych ${ }^{14}$. Przyszłość pokazała, iż raczej więcej było w tym kurtuazji, a konkrety rozbijały się o podejrzliwość administracji kolonialnej Francji lub inne postrzeganie potencjalnego polskiego osadnictwa, czego dowodziła sprawa Madagaska$\mathrm{ru}^{15}$. Dobrą lekcją okazała się też, stosunkowo dobrze znana, sprawa zainteresowania Polski Liberią. Kraj ten był oskarżany na forum Ligi Narodów o stosowanie nieludzkich praktyk na swym obszarze. Pojawiły się pomysły przejęcia kontroli nad państwem przez Lige lub wykluczenia go z tej organizacji. Rząd liberyjski zaczął szukać kontaktów w Europie, aby znaleźć sojusznika, a Polska, tzw. półstały członek Rady Ligi, nie obciążona kolonialną przeszłości, mogła wydawać się dobrym partnerem. Władze RP wyręczały się LMiK, która podpisała umowę z Liberią o wydzierżawieniu kilkuset akrów polskim osadnikom (kolonistom). Rokowania prowadzone przez aktywistów LMiK wyrwały się prawdopodobnie spod kontroli i powstało wrażenie, iż Rzeczpospolita ubiega się o protektorat nad tym afrykańskim krajem oraz organizuje transporty broni nad Zatokę Gwinejską. Władze II RP odcięły się od sprawy, chcąc uniknąć kompromitacji16.

\section{ANGOLA}

Za jeden z najbardziej odpowiednich obszarów dla ewentualnej polskiej akcji kolonialnej zainteresowane tym kręgi, skupione wokół Ligi (wówczas LMiR), uważały portugalską Afrykę. Początkowo uwagę koncentrowała Angola. W celu zbadania możliwości .....

12 AAN, Ambasada w Berlinie, teczka 423, k.19, Raport Delegata RP przy LN, Tytusa Komarnickiego oraz AAN, MSZ, sygn. 9583, Mkf. 25993, k. 14-16, pismo z Gabinetu Ministra do kierowników Wydziałów Resortu z 18.06.1936 z tezą aby unikać oskarżeń o rewizjonizm i nie dawać pretekstu Niemcom; też k. 25-36, pismo Z. Merdingera z lipca 1936 r., aby taktycznie zachować ostrożność w wysuwaniu żądań kolonialnych, co naruszyłoby relacje z mocarstwami broniącymi swojego stanu rzeczy oraz Niemcami; o konieczności zwiększenia emigracji Ukraińców oraz Żydów, w: AAN, MSZ, sygn. 9580, Mkf. B. 25990, k. 71-83, sprawozdanie z całokształtu spraw emigracyjnych i wytyczne na rok 1934, Warszawa 20.12.1933 oraz sygn. 9582, B. 25992, k. 39, Polskie tezy kolonialne i ekonomiczne oraz ich uzasadnienie 1935/1936, t. 2.

13 M.A. Kowalski, Kolonie Rzeczypospolitej, Warszawa 2005, s. 317.

14 T. Białas, s. 185

15 M. Jarnecki, Madagaskar w polskich koncepcjach i planach kolonialnych, „Sprawy Narodowościowe”, z. 28, 2006, s. 89-102 oraz M. Bretchen, Madagaskar für die Juden. Antisemitische Idee und politische Praxis 1885-1945, München 1998; również popularna pozycja, której autorem był M.A. Kowalski, Kolonie..., s. 312.

16 AAN, MSZ, sygn. 9765, Mkf. B. 26175 oraz M.A. Kowalski, Kolonie..., s. 329-346, gdzie autor przedstawił podstawowe informacje na ten temat i opatrzył ciekawym komentarzem. 
do Lizbony w pierwszej połowie roku 1928 udał się K. Głuchowski, aktywista Związku Pionierów Kolonialnych. Po niespełna półroczu do samej Angoli wybrała się delegacja LMiR w składzie: Franciszek Łyp, Jerzy Chmielowski, jak również Bronisław Noiszewski. Wnioski wizytujących były nader optymistyczne ${ }^{17}$. W 1928 r. trwały dyplomatyczne zabiegi o traktat handlowy z Portugalią - tu znajdować się miała także klauzula osiedleńcza. W tym samym roku 1929 zawiązała się spółka Polangola, która w przyszłości miała obsługiwać wymianę handlową z Portugalią i jej kolonią, oraz dwie instytucje mające organizować osadnictwo polskie: spółka Alfa i Towarzystwo do Kolonizacji Angoli. Jeszcze w grudniu 1929 r. udał się do tego afrykańskiego kraju hr. Michał Zamoyski. Stał się on właścicielem posiadłości Boa Serra, a przy okazji pełnił rolę przedstawiciela Polangoli. Zajmował się uprawą drzewek kawowych, ziemniaków, marchwi i hodowlą krów mlecznych. Z racji wahań koniunktury na kawę i plagi szarańczy poniósł straty, tak że musiał mu pomóc jego arystokratyczny ojciec z Polski, wysyłając 1250 funtów i prosząc MSZ o zezwolenie na transfer za granicę dewiz ${ }^{18}$. W ślad za nim wyjechali też inni: Juliusz Gebethner, z rodziny sławnych wydawców (plantacja Maria Krystyna), agronom Jerzy Chmielowski oraz panowie Dekański (plantacja Sandivia), Jesionowski (plantacja Chera), Rodziewicz i Paszkowski ${ }^{19}$.

Hrabiego Zamoyskiego odwiedził podczas swojej wielkiej afrykańskiej podróży odbytej w latach 1931-1936 znany swego czasu globtroter, poznański listonosz Kazimierz Nowak, który zamieszczał swoje relacje w krajowych czasopismach turystyczno-geograficznych - „Naokoło świata”, „Światowidzie”, „Na szerokim świecie” czy lokalnych periodykach: „Kurierze Poznańskim” i „Przewodniku Katolickim”. Pierwsze z nich wydawane było notabene przez oficynę Gebethner i Wolff. Zamoyski przez kilka dni gościł podróżnika i zapoznał go ze swoją plantacją. Nowak wspominał, że siedlisko hrabiego niedaleko Nowej Lizbony było kawałkiem Polski w Afryce. Miało to szczególne znaczenie dla poznańskiego pocztowca z tej racji, iż spędził tam święta Bożego Narodzenia roku 1934, spotykając się przy okazji z innymi polskimi osadnikami: Rodziewiczem, Barskim i Gebethnerem ${ }^{20}$. Według opinii globtrotera, angolańska Polonia liczyć miała 9 osób i 9 plantacji, nazywanych przez niego fazendami. Autor relacji, w przeciwieństwie do aktywistów LMiK, nie pozostawiał złudzeń:

„emigracja do krajów podrównikowych szczególnie dla Polaków jest grą hazardową [...], stawia się, bowiem życie i kapitalik, a wygrać może tylko jednostka nadzwyczaj silna [...]. Ażeby skierować emigrację do jakiegoś kraju, należy najpierw zbudować dla niej podstawy, których w Angoli nie stworzy nikt i dla nikogo. Najlepszy nawet rolnik polski, gdy stanie na płaskowyżu Angoli, jest zupełnie analfabetą w swoim zawodzie"21.

W logicznej sprzeczności z uwagami K. Nowaka stały inne artykuły prasowe, podgrzewające kolonialną gorączkę, stanowiąc swoisty wyraz zainteresowania Angolą. Nowak wnioskował, że wśród nich zdarzały się i nieodpowiedzialne, plotkarskie informacje ......

17 T. Białas, S. 188

18 AAN, MSZ, sygn. 9759, Mkf. B. 26169, k. 103, Wydział Konsularny Polityki Emigracyjnej do Komisji Dewizowej MSZ z 17.06.1939.

19 T. Białas, s. 189-190 oraz nie bez zastrzeżeń - nie wszystkie informacje tam zawarte zostały zweryfikowane, choćby mylnie podana data przyjazdu M. Zamoyskiego: http://pl.wikipedia.org/wiki/Kolonie_Polski, gdzie znajdują się też dane o powierzchni plantacji - największą miał posiadać J. Gebethner, 2000 ha, M. Zamoyski wedle jednej wersji (z wikipedii) 1000, a drugiej 600 ha - AAN, MSZ, sygn. 9759, Mkf., B.26169, k.103, a reszta zaś emigrantów po około 600 ha.

20 Zbiór relacji wydany przez oficynę Sorus: K. Nowak, Rowerem i pieszo przez Czarny Ląd. Listy z podróży afrykańskiej, Poznań 2007, s. 256-261.

21 Ibidem, s. 258 
o rzekomych zamiarach zakupu czy wręcz przejęcia Angoli przez Polskę, antagonizując stronę portugalską. W efekcie zaostrzyła ona prawo emigracyjne w stosunku do Polaków. Nie dziwi więc końcowa konkluzja Nowaka:

„emigracja w Angoli może być jedynie samorzutna, bezwarunkowo, nie masowa. Zresztą z powodu zapowiedzi dotyczącej 10000 rodzin z Polski, które miałyby osiedlić się w Angoli, rząd portugalski wydał nowe prawa dla tego kraju".

Potencjalny emigrant miał zdeponować w lokalnym banku sumę odpowiadającą 12 tys. złotych na 5 lat i płacić przez ten czas 5 funtów angielskich na osobę rocznie oraz osiedlić się od innego rodaka nie bliżej niż 10 kilometrów²2. Trudno się dziwić, że wskutek braku entuzjazmu do koncepcji kolonizacji polskiej, K. Nowak nie cieszył się specjalnymi względami MSZ i z prywatnych źródeł, niezależnie od własnej zapobiegliwości, zmuszony został czerpać fundusze ${ }^{23}$.

Wyczuwając pewnego rodzaju zaangażowanie władz, czyli tzw. „wyższych czynników", na scenę wkroczyli też spekulanci. Tak można chyba określić osobę Michała Franza z Przemyśla, który zakupił od włoskiego pośrednika (firma Impreso Coloniale Agricola d'Angola) prawo do dysponowania 3 majątkami o wielkości 60 tys. hektarów. Sugerował sprzedaż tej ziemi MSZ, aby mogło one uskutecznić akcję osadniczą. Określał się wyłącznym przedstawicielem na Polskę Towarzystwa Włoskich Kolonistów i Rolników. Po sprawdzeniu wiarygodności Franza i jego oferty, okazało się, że ziemię można kupić bezpośrednio i taniej, a przy okazji prezes włoskiej firmy, Aldo Garugi, miał zaprzeczyć w rozmowie z konsulem mediolańskim RP, że sprytny przemyślanin otrzymał faktyczny monopol ${ }^{24}$.

Finałem zainteresowania Angolą był pomysł zakupu kontrolnego pakietu akcji kompanii Cabinda w 1938 r. za niecałe 2 mln złotych, ale do tego nie doszło. W ostateczności według relacji J. Gebethnera w 1938 r. miało pozostawać w tym kraju 5 Polaków25.

\section{MOZAMBIK}

Pewne emocje i zainteresowanie w Polsce w drugiej połowie lat trzydziestych budziła inna portugalska kolonia w Afryce - Mozambik. Jak wynika z dokumentów oraz przypuszczeń Tadeusza Białasa, inicjatywa skierowania „polskiej ekspansji gospodarczo-ludzkiej”

\section{....}

22 "Morze”, 1931, nr 4, s. 30, T. Białas, s. 190, K. Nowak, s. 258-259 oraz nieco kontrowersyjna, ale chyba w tym akurat rzetelna: http://pl.wikipedia.org/wiki/Kolonie_Polski

23 Wstęp do pracy K. Nowaka, Rowerem..., autorstwa Łukasza Wierzbickiego, którego dziadkiem był poznański globtroter, s. 11.

24 AAN, MSZ, sygn. 9759, Mkf. B.26169, k. 3, List M. Franza do MSZ ze stycznia 1938, k. 135-136 oraz k. 93, Pismo M. Franza z 7.11.1937 informujące, że jest wyłącznym przedstawicielem na Polskę firmy włoskiej Impreso Coloniale Agricola d’Angola, co potwierdził w podobnym oświadczeniu z 23.03.1939; k. 25, Pismo starosty przemyskiego Remiszewskiego z informacją o Franzu z 2.03.1938; k. 80 i 87 pisma, pierwsze autorstwa Franza do Rady Ministrów RP o cenie ziemi w Angoli - ponoć 15 franków za hektar oraz drugie to opinia eksperta O. Szwarca, sugerująca że oferta Franza jest spekulacyjna i należy ją odrzucić, ponieważ ziemię w Angoli da się zakupić bez pośredników; k. 132-134, Konsulat Generalny RP w Mediolanie do Wydziału Emigracyjnego MSZ z 19.07.1939, gdzie konsul Żmigrodzki informuje o rozmowie z A. Garutim i jego wersji kontaktów z Franzem, z którym do transakcji nie doszło; też k. 128-129, Pismo z Wydziału Konsularnego i Polityki Emigracyjnej MSZ do MTO z sierpnia 1939 r. o firmie Impreso Coloniale Agricola d'Angola, która, choć zlikwidowana w roku 1937, została reaktywowana w następnym roku.

25 AAN, MSZ, sygn. 9729, k. 6-13, Notatka z 8.03.1938 r. dotycząca kompanii Cabinda z paragrafem A. Zarychty, szefa Wydziału Polityki Emigracyjnej; T. Białas, s. 191 i 192. 
do portugalskiej Afryki Wschodniej wyjść mogła od zamieszkałego tam od 1936 r. Emila Surycza. Ów polski inżynier, wcześniej pracownik kolei, posiadał początkowo połowę farmy Belmonte, a potem już całą Chicamba Real w prowincji Macequece oraz poszukiwał złóż miedzi i złota. W roku 1939 władze portugalskie wydały mu koncesję na eksploatację kopalni miedzi Edmundiana, niegdyś należącą do Niemców²6. To zapewne on zainspirował odpowiednie kręgi w LMiK oraz MSZ, które kwestię mozambicką podchwyciły. Najpierw, chyba w końcówce 1937 r. (?) zwrócił uwagę na rozległe, liczące 20 tys. ha $(200$ km²) obszary farmy „Lacreda”, sąsiadujące z majątkiem polskiego inżyniera. W resorcie spraw zagranicznych powstały nawet w związku z tym wstępne kosztorysy potencjalnej akcji kolonizacyjnej27. Nieco później, w styczniu 1938 r., Surycz zwrócił się do konsulatu w Capetown z informacją, że istnieje możliwość zakupu farmy Eland Springs w pobliżu jego własnej, w rejonie Macequece. Pracownik kapsztadzkiego konsulatu, radca Stanisław Lisiecki, po przeprowadzeniu na miejscu wizji lokalnej, zasugerował MSZ skorzystanie z oferty poprzez zakup całości lub połowy farmy (na spółkę z Suryczem). Polski inżynier zachęcał też LMiK, wyrażając gotowość zaproszenia do siebie dwóch polskich rolników. W maju 1938 r. do Mozambiku wybrało się dwóch rekomendowanych przez Ligę stażystów: Zbigniew Wiśniewski i Jan Olszewski28. Sprawę podjęło MTO, godząc się na transakcję i wysyłając pieniądze, które przyszły z pewnym opóźnieniem wiosna 1938 r. Opłaty transakcyjne wziął na siebie sam E. Surycz, któremu została złożona obietnica zwrotu poniesionych kosztów. Plany zakładały obsadzenie farmy, a właściwie jej połowy, Polakami. Na marginesie tych rozważań konsul kapsztadzki Jan Majewski zwracał uwagę, że kwestia finalizacji zakupu Eland Springs zbytnio zaangażowała szczupłe kadry jego placówki. Sugerował scedowanie problemu na zainteresowane MTO. Stwierdzał, że tylko instrukcje MSZ mogą to zmienić29.

MTO niedługo pozostawało właścicielem farmy. Szukając środków, odsprzedało ją polskiemu Żydowi, niejakiemu Garfinkielowi, który obiecywał zachowanie polskiego charakteru gospodarstwa. Jednak zawiódł pokładane w nim nadzieje i okazał się spekulantem. Postanowił odsprzedać farmę, nawet jeśli nie znajdzie Polaków. Doszło na tym tle do spięć między Garfinklem a Suryczem. Nie chciał także pokryć połowy kosztów manipulacyjnych, ale ostatecznie po kilku tygodniach ostrych targów udało się zawrzeć obu panom ugodę. Garfinkel, bardziej zainteresowany brytyjską Rodezją, sprzedał połowę farmy Suryczowi i jego nowo pozyskanemu wspólnikowi W. Dyjasowi ${ }^{30}$.

Inżynier Surycz po kilku miesiącach, późną wiosną 1939 r. zdecydował się sprzedać swoją farmę, koncentrując się na kopalni miedzi i miki Edmundiana (wspólnie z W. Dyjasem). Farma miała, co podkreślał, przejść w polskie ręce. Postulat ten wręcz stał się wa...

26 AAN, MSZ, sygn. 9760, Mkf. B.21170, k. 9-11, Załącznik do pisma z Konsulatu w Capetown do Departamentu Konsularnego i Emigracyjnego MSZ z informacją o stanie posiadania E. Surycza, luty 1938 oraz sygn. 9751, Mkf. B.21161, k. 22-26, Wniosek konsula J. Majewskiego w Capetown o odznaczenie E. Surycza Złotym Krzyżem Zasługi z 17.01.1939 r.

27 AAN, MSZ, sygn. 9729, k. 1-3, Projekt planu akcji kolonizacyjnej na terenach Lacredy, bez daty, ale z kontekstu wynika, że zapewne to koniec 1937 r.; powstać miałoby 100 plantacji na rodzinę miało przypadać 11 tys. zł; akcję miało nadzorować Międzynarodowe Towarzystwo Osadnicze (MTO).

28 AAN, MSZ, sygn. 9760, Mkf. 21170, k. 51, Notatka W. Drymmera, Dyrektora Departamentu Konsularnego MSZ z 9.05.1938.

29 AAN, MSZ, sygn. 9760, Mkf. B.261170, k. 34-35, Pismo konsula Majewskiego z Capetown do MSZ, 24.03.1938.

30 ZZN, MSZ, sygn. 9760, Mkf. B. 261170, k. 62 i 64, Pisma z MTO do MSZ z 24.05.1938 oraz Notatka Wydziału PE MSZ z 30.06.1938; k. 130-131, List E. Surycza z Chicamba do konsula J. Majewskiego z 29.11.1938 oraz k. 169-170, 173-174 i 177-179, Listy konsula J. Majewskiego w Capetown do MSZ o ugodzie Grafinkla z Suryczem oraz jego wspólnikiem Dyjasem z 6.01. i 12.01.1939. 
runkiem. Do roli nowego właściciela szykował się W. Czarnowski. Problemy z transferem dewiz przedłużyły się do czasu wybuchu wojny i wydaje się, że do transakcji nie doszło ${ }^{31}$.

Pomimo niesmaku wywołanego postawą Garfinkla, w MSz nie zaniechano myśli o Mozambiku, jako możliwym punkcie polskiej akcji osadniczo-kolonizacyjnej. Po pierwsze, zamówiono u znanej publicystki-podróżniczki - Marii Zakrzewskiej opracowanie dotyczące tej portugalskiej kolonii, w którym analizowała ona zasoby gospodarcze, potencjał rolniczy i szanse osadnictwa. Powstało ono na początku 1939 r. ${ }^{32}$ Po wtóre, powróciła sprawa Lacredy - od nazwiska portugalskiego właściciela. Jeden z dokumentów cytowany przez T. Białasa postulował w preliminarzu budżetowym Wydziału Polityki Emigracyjnej MSZ przeznaczenie 395 tys. złotych (wówczas równoważność około 15 tys. funtów) w latach 1939-1940 na zakup tych obszarów i przygotowanie ich pod osiedlenie przybyszy z Polski. Cena za hektar miała wynosić 13 złotych, co odpowiadałoby 10 szylingom. Na negocjacje z Lacredą miał wybrać się sam konsul kapsztadzki J. Majewski³. Kolejnym argumentem, wręcz kuriozalnym dowodem zainteresowania Mozambikiem, były rozważania J. Kozielewskiego z marca 1939 r. zaprezentowane w notatce „Ekspansja polska w Afryce". Uważał on, że zbyt wielkim ryzykiem byłoby prowokowanie Francji czy Anglii postulatami kolonialnymi, wyjątek może czyniąc w przypadku Madagaskaru, gdzie strona francuska zajmowała niejednoznaczne w pewnym momencie stanowisko. Jeżeli odpadały imperia kolonialne Wielkiej Brytanii i Francji, autor postulował wzięcie na celownik portugalskiego Mozambiku. Był on dosyć luźno związany z metropolią. Portugalia pozostawała państwem słabym, zależnym od Anglików i w razie konfliktu nie sprostałaby silniejszej Polsce dysponującej poparciem Zachodu ${ }^{34}$. Nasuwa się tutaj kąśliwa uwaga o myśleniu życzeniowym niektórych pracowników polskiej służby dyplomatycznej.

Dwoma portugalskimi koloniami - Angolą i Mozambikiem - zainteresował się jeszcze jeden Polak, Tadeusz Gebethner. Pochodził on z tej samej rodziny wydawców co osiadły w Angoli jego krewniak. Zastanawiał się nad tym krajem, ale ostatecznie wybrał po konsultacjach Mozambik ${ }^{35}$.

\section{AMERYKA ŚRODKOWA I KARAIBY}

Wśród potencjalnych destynacji polskiej akcji osadniczej, a pośrednio i kolonialnej, znalazły się też państwa Ameryki Środkowej, Nikaragua czy nawet karaibska Dominikana. Największa z tzw. bananowych republik wzbudziła na początku roku 1938 zainteresowanie za sprawą działalności inż. Stanisława Czarnockiego, znanego w tym rejonie świata biznesmena, który dorobił się majątku na handlu bronią podczas wojny hiszpańskiej. Kusić go miała egzotyczna przygoda i wielkie plany. Czarnocki, dzięki swym koneksjom i niemałym pieniądzom, poznał dyktatora Anastasio Somozę seniora, który .....

31 AAN, MSZ, sygn. 9759, Mkf. B. 26169, k. 111-112, Pismo konsula J. Majewskiego z Capetown do Wydziału PE MSZ z 6.06.1939.

32 AAN, MSZ, sygn. 9759, Mkf. B.26169, k. 11-23, Opracowanie dotyczące Mozambiku M. Zakrzewskiej z 2.01.1939, autorka sugerowała emigrację indywidualną, nie zaś masową.

33 AAN, MSZ, sygn. 9995, MKf. B.26015, k. 157, Preliminarz budżetowy Wydziału PE MSZ na rok 1939-1940, w którym znajdujemy kontynuację planów z końca 1937 r. (patrz przypis 27); też sygn. 9761, Mkf. B.26171.

34 AAN, MSZ, sygn. 9937, k. 50, Notatka J. Kozielewskiego „Ekspansja w Afryce” z 28.08.1939 i T. Białas, s. 192 komentujący również ów kuriozalny dokument.

35 AAN, MSZ, sygn. 9759, Mkf. B.26169, k. 99, Pismo T. Gebethnera do Departamentu Konsularnego MSZ z 18.01.1939. 
zachęcił go do idei sprowadzenia osadników-kolonistów z Polski, z wyłączeniem, na życzenie prezydenta Nikaragui, elementu żydowskiego. Czarnocki zjawił się w nowojorskim konsulacie Rzeczypospolitej, zachęcając do zajęcia się sprawą akcji osadniczej, obiecując wyłożenie na początek z własnej kieszeni 100 tys. dolarów i sfinansowanie przyjazdu misji eksperckiej. Według konsula Sylwestra Graszki, gość miał oświadczyć, iż regionalni dyktatorzy potrzebują ludzi z gotówką i kwalifikacjami, aby mieć dla siebie bezpośrednie korzyści ${ }^{36}$. Wiosna i jesienia 1938 r. podczas wizyty S. Czarnockiego w Polsce odbyło się szereg spotkań inżyniera z kierownictwem Departamentu Konsularnego MSZ, odpowiedzialnego za sprawy emigracji. W jednej uczestniczył Wiktor T. Drymmer, a w drugiej, obok eksponowanych pracowników MSZ, jak Tomasz Ziętkiewicz, zastępca A. Zarychty, z Wydziału Polityki Emigracyjnej oraz członkowie zarządu LMiK: gen. Stanisław Kwaśniewski, Jan Dębski i Hubert Sukiennicki. Władze polskie podjęły temat, sugerując w rozmowach z Czarnockim wyekspediowanie do Ameryki Środkowej przede wszystkim przedstawicieli mniejszości narodowych, aby pozbyć się „niepożądanego elementu etnicznego". Niepokój budziły jednak wysokie koszty sprowadzenia tam osadników (na 3 osoby około 5000 zł). Stąd pojawiły się wątpliwości co do skali osadnictwa w Nikaragui, zbyt optymistycznie planowanego na 50 tys. rodzin! Życzeniem uczestników drugiej, wrześniowej, narady stało się, aby wstępna, rozpoznawcza ekspedycja miała prywatny charakter i odbyła się bez przesadnego rozgłosu [czyżby wnioski po sprawie liberyjskiej - M. J. ?]. Czynniki rządowe radziły jednak zbadać ewentualną reakcję USA, kierujących się doktryną Monroe'a, aby nie wejść w kolizję z interesami tego mocarstwa $^{37}$. Czarnocki zapewne przyczynił się do wysłania zapowiedzianej misji eksperckiej, ponieważ Józef Zieliński, jeden z jej uczestników i znajomy organizatora jeszcze z czasu wspólnej pracy na kolei (PKP), przedstawił po powrocie z Nikaragui, poselstwu w Meksyku relację z wyprawy. Podkreślał dobre relacje Czarnockiego z Somozą i życzliwość dyktatora. Strona nikaraguańska liczyła na podniesienie poziomu lokalnego rolnictwa. Zapewniała asystę wojskową na początku akcji, podkreślała dobre warunki, spokój w kraju i brak ksenofobii. Oczekiwała głównie Polaków, nie żywiąc entuzjazmu do przybyszy żydowskiego pochodzenia. Imigranci mieliby zamieszkać we wschodniej części kraju, bliżej Bluefields, pomiędzy rzekami Mico i Rama, gdzie być może w przyszłości powstałby alternatywny w stosunku do panamskiego kanał łączacy Atlantyk z Pacyfikiem ${ }^{38}$. Sprawa ewentualnej polskiej akcji osadniczej wzbudziła niekoniecznie miłe zainteresowanie w nieodległym Meksyku, gdzie ukazały się nieżyczliwe komentarze o „szykującej się polskiej inwazji na Nikaraguę" 39.

W świetle rewelacji polskiej prasy, fantastyczne zgoła możliwości kolonizacji miały się otwierać w stosunkowo nieodległej od Nikaragui Dominikanie. Było to na marginesie ożywionej w drugiej połowie lat trzydziestych dyskusji w polskiej publicystyce o ewentualnej migracji rodzimych Żydów na Madagaskar. Ponoć władze tego kraju, trzymanego w garści przez innego sławnego dyktatora Trujillo, zaproponowały przyjęcie miliona Żydów z Polski i Niemiec, ale w rzeczywistości była to sensacja o randze dziennikarskiej kaczki ${ }^{40}$.

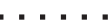

36 AAN, MSZ, sygn. 9827, Mkf. B.26237, k. 15-16, Konsulat Nowy Jork do MSZ, 1.03.1938.

37 Ibidem, AAN, MSZ, sygn. 9827, Mkf. B. 26237, k. 18-19 i k. 41-45, Notatki: z konferencji przeprowadzonej w MSZ 28.04.1938 i zebrania przeprowadzonego w Hotelu Europa 22.09.1938.

38 Ibidem, AAN, MSZ, sygn. 9827, Mkf. B. 26237, k. 3-6, Pismo charge d'affaires w Meksyku Mieczysława Marchlewskiego do Wydziału Emigracyjnego MSZ z 3.02.1939.

39 AAN, MSZ, sygn. 9827, Mkf. B.26237, k. 15-16, Konsulat Nowy Jork do MSZ, 1.03.1938.

40 "Goniec Warszawski”, 15.05.1937 oraz materiały w AAN, MSZ, sygn. 9929; o polskim zainteresowaniu Madagaskarem zob. M. Jarnecki, Madagaskar w polskich koncepcjach..., s. 89-102. 


\section{EKWADOR}

Wśród możliwych destynacji polskiej akcji osadniczo-kolonialnej, niezależnie od Brazylii i Argentyny, uważanych za najważniejsze w tym regionie kierunki, znalazły się też Ekwador, Boliwia i Paragwaj. Tradycje zainteresowania się Ekwadorem miały już swoją historię, ponieważ w końcu XIX w. (1882) odwiedziło go kilku polskich podróżników i badaczy: geolog Józef Siemiradzki (brat stryjeczny malarza Henryka) i zoolog Jan Sztolcman, a kilka dekad wcześniej Józef Warszewicz ${ }^{41}$. W państwie tym w latach trzydziestych zamieszkiwać miało według słów konsula honorowego w Quito, Kazimierza Frycza, tylko kilku Polaków, nie licząc grupy Żydów wywodzących się z kraju nad Wisłą. Konsul miał przeprowadzić w lutym 1939 r. w ekwadorskim MSZ rozmowy, ale wykazały one nikłe zainteresowanie imigrantami z Polski. Władze tego dość biednego państwa oczekiwały pokrycia 2/3 kosztów przyjazdu osadników przez nich samych lub instytucje wysyłające. Po kilku tygodniach otwarły się jednak, według Frycza, perspektywy przyjęcia emigrantów pochodzenia ukraińskiego. Radził pokryć koszty podróży szwedzką linią za 150 dolarów w klasie turystycznej, uważając to za opłacalne. Konsul stwierdzał także, że najlepszą lokalizacją byłaby osada Lita koło Ibery, położona na wysokości od 800 do 1500 metrów, z chłodniejszym przez to klimatem, gdzie nie występuje malaria. Rząd ekwadorski dałby tylko ziemię (60 tys. ha), a na resztę nie byłoby co od strony gospodarza liczyć. Mogłoby tam zamieszkać 150-200 rodzin ukraińskich ${ }^{42}$.

\section{PARAGWAJ}

Paragwaj mógł zapewne zainteresować pewne sfery LMiK oraz MSZ swoim sąsiedztwem z centrami polskiej emigracji w Argentynie i Brazylii. Tam dotarli również wcześniej inni polscy odkrywcy i podróżnicy, jak niestrudzony J. Siemiradzki w swojej drugiej podróży do Ameryki Łacińskiej w 1892 r., a następnie Witold Szyszłło w 1913 i Mieczysław Lepecki w 1925 r. ${ }^{43}$ Z czasem i tutaj, najczęściej z Argentyny, trafili polscy osadnicy, ale było ich niewielu. Jak wskazuje anonimowa relacja jednego z nich zamieszkałego koło Encarnacion, zdarzało im się poprawić swój materialny status ${ }^{44}$. Na początku lat trzydziestych powstała w tych okolicach nawet kolonia „Fram”, o wielkości 8000 ha, którą zainteresowali się polscy dyplomaci z bliskiej fizycznie Argentyny (po drugiej stronie Parany). Właścicielem wydzierżawianych gruntów i agentem firmy Mifos Suchan, organizującej kolonizację paragwajskiego południa, był bliżej nieznany biznesmen Christopherson, nastawiony na zysk. Liczebnie przeważać miał tam element ukraińsko-rusiński i koegzystowały ze sobą religie prawosławna, unicka i katolicka. Istniała tam również szkoła polska, założona przez Edwarda Januszewicza. Podczas wizy-

\footnotetext{
... .

41 M. Paradowska, Polacy w Ameryce Południowej, Wrocław 1977, s. 187-195 i 240; W. Słabczyński, Polscy podróżnicy i odkrywcy, Warszawa 1988, s. 284 i 293-296 oraz M. Graniczny, J. Kacprzak, L. Marks, H. Urban, J. Siemiradzki - geolog niezwykły, „Przegląd Geologiczny”, vol. 56, nr 5, 2008 , s. 368.

42 AAN, MSZ, sygn. 9823, Mkf. B. 26233, k. 2-5, Konsul K. Frycz do MSZ, 21.12.1938; k. 2-12, K. Frycz do MSZ, 2.02.1939; k.27-28, K. Frycz do A. Zarychty z Wydziału Emigracyjnego MSZ, 26.02.1939 i k. 112-157, Analiza możliwości akcji osadniczej na bazie raportów Frycza z marca 1939.

43 M. Paradowska, Polacy w Ameryce..., s. 199-200, 268 i 271-272; M. Graniczny, J. Kacprzak, L. Marks, H. Urban, J. Siemiradzki-geolog..., s. 368.

44 Pamiętniki emigrantów. Ameryka Południowa, Warszawa 1939, 464-469; też M. Paradowska, s. 156.
} 
tacji kolonii właściciel godził się na powołanie nowego administratora, człowieka zaufania z polskiego poselstwa z Buenos Aires, pod warunkiem przyjazdu nowej partii osadników ${ }^{45}$. Sprawa się przeciągała. Pod koniec okresu międzywojennego pojawiały się projekty ożywienia tej kolonii przez wysłanie kolejnej grupy osadników ${ }^{46}$.

BOLIWIA

Także w latach trzydziestych Boliwia pojawiła się w kontekście akcji osadniczo-kolonialnej. Niezależnie od wspomnianego podróżnika i botanika J. Warszowicza (połowa XIX w.), na przełomie XIX i XX w. rolę polskiego pioniera w tym kraju odgrywał pracujący tam w zarządzie kopalń inż. Józef Jackowski ${ }^{47}$. Rząd RP negocjował w latach 1937-1939 ze swoim boliwijskim odpowiednikiem umowę emigracyjną o charakterze koncesji, licząc na wyjazd 200 rodzin, z możliwością powiększenia limitu do 500 rocznie w pespektywie 9 lat. Boliwijskim gospodarzom zależało na pozyskaniu rolników, co było także w polskim interesie. Rząd RP widział przecież w emigracji jeden ze sposobów rozwiązania problemów przeludnionej wsi, zwłaszcza na kresach wschodnich. Władze boliwijskie miały przekazać ziemię, zapewniały bezpłatny transport od portu wylądowania (Boliwia nie miała formalnie od 1884 r. - faktycznie już 5 lat wcześniej, dostępu do morza!), zwolnienie od opłat celnych, pocztowych i paszportowych na rok. Godziły się również na założenie polskich szkół ${ }^{48}$. Leżało to na sercu stronie polskiej, zwłaszcza że w owym czasie Brazylia, rządzona przez populistę Getulio Vargasa, w imię unifikacji państwa i narodu ograniczała prawa europejskich grup etnicznych do kultywowania swojej odrębności w ramach tzw. nacjonalizacji.

Rejonem potencjalnego osadnictwa z Polski miały się stać podgórskie okolice Todos dos Santos (prowincja Cochabamba) nad dopływem rzeki Chapre - Coni, gdzie planowano wybudowanie Portu Polonia. Poważnym problemem był brak możliwości dotarcia lądem do planowanego miejsca, co podkreślali wizytujący te strony leśnik Stefan Dębicki oraz przedstawiciel MTO, inż. Edward Klasse. Droga dochodziła tylko do wspomnianego miasta Todos, a dalej należało albo płynąć okrężnie rzeką (około 177 km) lub dobudować brakujące 53 kilometry trasy. Logistyka dosyć skutecznie utrudniała realizację ambitnych koncepcji boliwijskich władz, a lokalne czynniki wykazywały daleko idącą niefrasobliwość 49 .

Rozmowy przewlekały się z kilku powodów. Boliwijczycy pragnęli darmowy transfer zapewnić imigrantom tylko od swojej granicy, nie zamierzali dyskutować o możliwości częściowej choćby refundacji podróży, uważali iż Polska powinna wspomóc budowę .... .

45 AAN, MSZ, sygn. 9828, Mkf. B. 26238, k. 1-2, M. Pankiewicz, radca poselstwa RP w Buenos Aires do MSZ, 23.03.1933; k. 5-8 Relacja z wizytacji kolonii Fram do poselstwa RP Buenos Aires, 5.01.1933; k. 10, Poselstwo RP w Buenos Aires do Wydziału Emigracyjnego MSZ, 2.05.1933; o szkole polskiej M. Paradowska, s. 156

46 AAN, MSZ, sygn. 9829, B. 26239; w teczce materiały (umowy i ich projekty z firmą sprowadzającą osadników) dotyczące kolonii Fram z lat 1938-1939

47 M. Paradowska, s. 220 i W. Słabczyński, s. 285-286.

48 AAN, MSZ, sygn. 9542, Mkf. B. 25949, k. 5-9, 12-13, 20-24, Umowa imigracyjna pomiędzy RPA Boliwią z 31.12.1937 oraz komentarze i notatki skierowane do szefa resortu.

49 Ibidem, k. 33-36, Pismo sekretarza konsulatu w Buenos Aires, W. Dostala do konsula Kurnikowskiego, 17.12.1937 z informacją o podgórskim charakterze okolic Todos, średnia wysokość 500-600 m, k. 134-133, Relacja S. Dębickiego spisana w konsulacie w Buenos Aires, 4.02.1938; sygn. 9543, Mkf. B.25950, k. 78-113, Relacja E. Klasie z października 1938 r. 
szkół. Nie do końca określony został status języka polskiego, który gospodarze woleliby zmarginalizować (istniały projekty, aby spadł do roli nadobowiązkowego) na rzecz hiszpańskiego. Opóźniali też prace przygotowawcze - budowy infrastruktury dla przyszłej imigracji. Niezbędne opłaty rzeczywiście były wysokie. Cena przejazdu statkiem do najbliższego portu, chilijskiej Arici, wynosić miała niecałe 800 złotych, stąd pociąg do La Paz 26,50 zł, a do tego dochodziły niewiele mniejsze dodatkowe opłaty: zezwolenia urzędowe, wiza i tłumaczenia niezbędnych dokumentów (świadectwo chrztu, zaświadczenie lekarskie, świadectwo moralności i niekaralności, zaświadczenie o wykonywanym zawodzie i kwalifikacjach i o posiadaniu kapitału w wysokości minimum 50 funtów) ${ }^{50}$.

Pojawiły się też problemy z „jakością" bazy lokalowej, odbiegającej od zapowiadanej przez Boliwijczyków wizji mieszkań dla osadników. Inżynier Klasie w swoich raportach podniósł tę kwestię. Według jego obserwacji strona boliwijska szykowała nie zapowiadane domy czy baraki, ale konstrukcje przypominające szałasy. Podobne uwagi znalazły się w notatce świeżo mianowanego konsula honorowego w La Paz, Edwarda Paciorkowskiego ${ }^{51}$. Gospodarze naciskali z kolei na gwarancje rządowe strony polskiej o charakterze finansowym, na co ta nie chciała udzielić jednoznacznej odpowiedzi52. Z kolei w 1939 r. pojawiły się alternatywne miejsca wydania koncesji osadniczej w rejonie Santa Cruz, ale wizytując te strony, Paciorkowski stwierdzał, iż choć są żyzne, to malaryczne ${ }^{53}$.

W toku żmudnych negocjacji udało się skłonić Boliwijczyków do częściowego pokrycia kosztów przyjazdu. Było to już w 1939 r. i przewlekała się też wymiana dokumentów ratyfikacyjnych, jak również wizyta w Warszawie oficjalnego przedstawiciela rządu Boliwii. Miał to uczynić mianowany boliwijskim posłem w Berlinie, Hugo Ernst - potomek niemieckich emigrantów, ale jego przyjazd do Europy opóźniał się. Potem przyszedł pamiętny wrzesień i sprawa nie doczekała się finalizacji54.

\section{KONKLUZJE}

Reasumując, należy przyznać, że polskie koncepcje kolonialne były bardziej emigracyjno-osadniczymi niż kolonialnymi sensu stricte. Nie ma wątpliwości, iż bardziej poruszała wyobraźnię i emocje ta pierwsza nazwa. Terminologii kolonialnej używano jednak głównie na użytek wewnętrzny, ale problem tkwił w meritum sprawy, a nie w nazewnictwie. Międzywojenna Polska borykała się z wieloma bolesnymi kwestiami społecznymi i et. . . .

50 AAN, MSZ, sygn. 9542, Mkf. B. 25949, k. 22-24; Notatka informująca o kosztach. I tak, wiza boliwijska 150 zł, tranzytowa chilijska 60 zł, a 600 zł tłumaczenia nieco dziwacznych dokumentów; k. 130-133, W. Drymmer do Poselstwa w Buenos, luty 1938, gdzie jest mowa o różnym podejściu oraz interpretacji kwestii szkół polskich; też sygn. 9543, Mkf. 9543, B. 25950, k. 11-12, Wymiana pism pomiędzy Brazylią a MSZ, 11-13.05.1938.

51 AAN, MSZ, sygn. 9543, Mkf. B. 25950, k. 130-131, Pismo E. Klasse z La Paz do MSZ z 19.12.1938, w którym przeciwstawia się optymistycznym wizjom Boliwijczyków i M. Lepeckiego; sygn. 9542, Mkf. B. 25949, E. Paciorkowski do MSZ, k. 161-196 z maja-czerwca 1938 r.

52 AAN, MSZ, sygn. 9544, Mkf. 25951, k. 2, Pismo MSZ poselstwa w Buenos Aures z lutego 1939.

53 Ibidem, k. 84-111, Raport Poselstwa w Buenos Aires z lutego 1939 r. z podróży służbowej odbytej przez Z. Paciorkowskiego w rejon Santa Cruz.

54 Ibidem, w tym samym liście znajduje się informacja, iż Boliwijczycy gotowi są pokryć 2/3 kosztów przejazdu, o tym też k. 179, Pismo E. Klasie do MTO o dalszych postępach w negocjacjach z 2.07.1939według autora rząd boliwijski godził się na udzielenie pożyczek imigrantom, stąd też wniosek o uhonorowanie negocjatora Carlosa Salinasa - został ministrem rolnictwa, jakimś polskim odznaczeniem - k. 4-5, z 24.01.1939 r.; o zwłoce wynikającej z odkładania przyjazdu właściwej osoby z Boliwii na podpisanie umowy, w: AAN, MSZ, sygn. 9543, B. 25951, k. 62, Raport posła Z. Kurnikowskiego z Buenos Aires do MSZ z 30.09.1938; poseł Kurnikowski w kilku innych pismach wspominał o fascynacji faszyzmem wielu urzędników w boliwijskim MSZ, szczególnie po powrocie z Europy. 
nicznymi, jak: przeludnienie, bezrobocie i spory odsetek niekoniecznie lojalnych mniejszości narodowych. W tym kontekście zabiegi o umożliwienie wyjazdu czy to do pracy, czy w charakterze osadników obywateli RP przez władze tegoż państwa, wydawały się w jakimś stopniu racjonalne. Niestety, nadmiernie podgrzewane nastroje, osobliwa argumentacja, polityczna wrzawa z elementami tomtradacji i myślenie życzeniowe, niepełne rozeznanie sytuacji międzynarodowej - nie mówiąc o relatywnej słabości państwa - lokowały te pomysły w rzędzie fantastyki. Aby uwiarygodnić własne oczekiwania i pretensje, wypadało zrozumieć innych, silniejszych graczy przejawiających tendencje zamorskiej ekspansji. Polskie zainteresowanie problematyką kolonii lub co najmniej uzyskania dostępu do surowców i pozbycia się nadwyżki populacji, szczególnie etnicznie niepolskiej, powodowały, iż prominentni działacze LMiK oraz rządzącego obozu ze zrozumieniem potraktowali włoską napaść na Etiopię - Abisynię ${ }^{55}$. W świetle późniejszych doświadczeń roku 1939 mogłoby to wydać się nieco schizofreniczne.

Za polskimi postulatami i ambicjami, nawet jeśli częściowo uzasadnionymi realiami społeczno-gospodarczymi, nie stała realna siła. W zmieniającej się rzeczywistości po pierwszej wojnie trąciły one też anachronizmem, a sposób argumentowania momentami bywał zadziwiający.

POLITICAL FANTASY OR NECESSITY? POLISH COLONIAL PLANS IN PORTUGUESE AFRICA, NICARAGUA, BOLIVIA AND ECUADOR

\section{Summary}

In interwar Poland some institutions intended to solve part of the country's economic and ethnic problems by acquiring colonies abroad. Accordingly, the Polish Foreign Ministry as well as special institutions such as The Union of Colonial Pioneers and The Sea and Colonial League undertook some projects. Poland, a member of the victorious Ententa, was supposedly entitled to ca. $10 \%$ of the area of the former German colonies, e.g. in Cameroon or Togo, or in another condominium belonging to one of the colonial powers. These plans were made more specific in the mid-1930s.

Argentina and Brazil, as well as Madagascar, were considered as natural goals of Polish emigration policies. Then Poland became interested in settlements in the colonial dominions of Portugal in Africa, i.e. Angola and Mozambique, and some time later, also in some countries of Latin America and the Caribbean. As for Bolivia, the aim was to send as many Ukrainians as possible to the mountainous area of Todos dos Santos (Province of Cochabamba). Other places in the vicinity of the town of Ibera in Ecuador were also considered by the Polish authorities as suitable for settlers, predominantly from Poland's eastern borderlands. In the region of Encarnacion in Paraguay, a colony "Fram" was established in the 1930s. Nicaragua, too, was considered a convenient place for Polish colonisation, the result of an effort undertaken by the Polish businessmen Stanisław Czarnocki, who was a personal acquaintance of the local dictator, the famous Anastasio Somoza senior. For their part, according to some completely incredible gossip, Dominica was supposedly ready to accept some hundreds of thousands of Polish Jews.

All in all, these Polish colonial ambitions were unsuccessful, mainly due to the lack of sufficient Polish state power to make them into reality.

Keywords: colonial ambitions, interwar Poland; The Sea and Colonial League, Latin America: Bolivia, Ecuador, Paraguay, Nicaragua, Dominica; Portuguese Africa: Mozambique and Angola

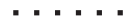

55 AAN, MSZ, sygn. 9582, Mkf. B.25992, k. 38, Notatka z przełomu 1935/1936 r. oraz T. Białas, s. 179. 